\title{
Equity Incentives and Corporate Fraud in China
}

\author{
Lars Helge Haß ${ }^{*}$ Monika Tarsalewska ${ }^{\dagger}$ Feng Zhan ${ }^{\ddagger}$
}

\begin{abstract}
This paper explores how managers' and supervisors' equity incentives impact the likelihood of committing corporate fraud in Chinese-listed firms. Previous research has shown that corporate fraud in China is a widespread phenomenon and has severe consequences for affected firms and executives. However, our understanding of the reasons fraud is committed in a Chinese setting have been very limited thus far. This is an increasingly important topic, because corporate governance is rapidly changing in China, and it is unclear whether adopting the executive compensation practices of the West is appropriate for Chinese firms. We show that managers' equity incentives increase their propensity to commit corporate fraud. We also find that this effect is more pronounced for state-owned firms. However, we find a negative but not significant relationship between the equity incentives of the supervisory board and the incidence of fraud.
\end{abstract}

Keywords Equity Incentives, Corporate Fraud, Corporate Governance, Ownership Structure, Chinese Economy

\footnotetext{
* Lancaster University Management School, Lancaster University, LA1 4YX, Lancaster, United Kingdom, Phone: +44 1524 - 593981, Fax: +44 1524 847321, e-mail: 1.h.hass@lancaster.ac.uk.

${ }^{\dagger}$ University of Exeter Business School, XFI building, Streatham Campus, Rennes Drive, Exeter EX4 4ST, United Kingdom, Phone: +44 1392 726256, e-mail: M.Tarsalewska@exeter.ac.uk.

* Boler School of Business, John Carroll University, 1 John Carroll Blvd, University Heights, Ohio, United States, email: fzhan@jcu.edu.
} 


\section{Introduction}

Corporate fraud is a serious threat to financial markets. Previous literature has identified managers' equity incentives as one potential cause of fraud. The basic notion behind this relationship is that the fraudulent behavior, before it is discovered and announced, may increase a firm's stock price and risk, and therefore the value of an executive's equity portfolio.

A wide range of literature has explored the relationship between equity incentives and corporate fraud. However, the results of these studies are mixed. Additionally, these studies have focused on the U.S., whereas the Chinese economy, which features unique forms of ownership structure and corporate governance, has been left unexplored.

Despite major improvements in their legal framework, corporate fraud in China continues to be widespread, potentially hindering economic development (Tian, 2008; Huang and Rice, 2012). Chinese-listed companies are well known for behavior such as inflating profits, creating fictitious transactions, and making false disclosures (Chen et al., 2006). Corporate fraud weakens the efficiency of the financial markets (Ball, 2009), and has extremely negative consequences for firms. For example, announcements of fraud can dramatically affect firm value. Chen et al. (2005) report that firms can lose, on average, $15 \%$ to $25 \%$ of their value as a result of enforcement actions taken by the China Securities Regulatory Commission (CSRC) or the Shanghai and Shenzhen stock exchanges. ${ }^{1}$ Fraud generally weakens trust in firm disclosures as well, and it increases uncertainty about financial statements, which ultimately leads to higher costs of raising capital (Graham et al., 2008).

The factors that lead to corporate fraud in China have not yet been studied extensively. Several researchers have found that board composition and ownership structure can affect the incidence of fraud (Chen et al., 2006; Jia et al., 2009; Hou and Moore, 2010). Managers' equity 
incentives, which are intended to control risk-taking behavior and align long-term investment policies with shareholders' interests, may also have an impact. The popularity of incentive-based components in executive compensation in China has grown dramatically in recent years. But we cannot yet fully determine whether specific components of executive compensation encourage fraudulent activity.

Our goal here instead is to examine the factors preceding corporate fraud in China, and to provide evidence that will help to advance further research on this topic. In particular, we study whether the equity incentives of management and the supervisory board promote corporate fraud activities in Chinese-listed firms. We define fraudulent firms as those facing enforcement actions by the China Securities Regulatory Commission (CSRC) and other regulatory authorities in response to company and individual violations that relate to financial misreporting and disclosure.

Studying equity incentives and fraud, in general and specifically in China, is important for many reasons. First, according to a recent report in The Economist, ${ }^{2}$ the Chinese economy is now responsible for almost 50\% of worldwide GDP growth. Second, China has a rapidly growing capital market that has also become one of the world's major financial markets. Third, Chinese authorities have encouraged the adoption of Western practices regarding executive compensation driven by stock performance. This raises the question of whether equity-based pay is appropriate for Chinese executives under existing legal standards, particularly in light of recent corporate scandals in the West.

Our study is based on the sample of firms listed on the Shanghai and Shenzhen stock exchanges from 2000 through 2010. We test the effect of equity incentives on the likelihood of 
committing corporate fraud while controlling for ownership characteristics and corporate governance mechanisms specific to China.

We find a significant and positive relationship between the equity incentives of management and corporate fraud. This evidence is consistent with other studies finding that equity incentives for management can fuel corporate fraud. However, we find a negative but not significant relationship between equity incentives of supervisory board members and corporate fraud. Furthermore, our further analysis reveals that the effect of equity incentives on corporate fraud is more pronounced in state-owned enterprises (SOEs) than in non-SOEs. This result may be attributable to the fact that SOE management is more constrained from affecting their level of compensation, and weaker monitoring creates more opportunities to commit fraud. Therefore, SOE management may have stronger incentives, and lower expected costs, to fraudulently affect stock prices and increase wealth.

Our paper contributes to the existing literature on corporate fraud in China in the following ways. First, the results in the previous literature studying the effect of equity incentives on corporate fraud are mixed. On the one hand, a positive effect has been found in, for example, Bergstresser and Philippon (2006), Burns and Kedia (2006), and Armstrong et al. (2013). On the other hand, Erickson et al. (2006) and Armstrong et al. (2010) document no effect of equity incentives on corporate fraud. Therefore, we believe additional evidence is important.

Second, although fraud itself has been studied extensively, the effect of equity incentives on corporate fraud has only been studied in developed countries. China, as an emerging market, differs from developed countries along many dimensions (institutional setting, ownership structure), and offers a quite unique research setting. Previous literature found that the phenomenon of corporate fraud in China differs significantly from that in developed countries 
(Cumming et al., 2011). Therefore, we believe that China provides a rich environment in which to study the role of equity incentives, especially as it has gradually introduced many of the same executive compensation structures commonly found in Western economies.

Third, the impact of state ownership on the relationship between equity incentives and corporate fraud has not been studied before. China again offers a unique setting for this topic because more than half of Chinese-listed firms remain state-owned. Also, the Chinese state is exceptionally influential in both the legal and regulatory systems, affecting judicial and regulatory independence (Allen et al., 2005). This creates a potential conflict of interest that has serious consequences for internal and external corporate governance mechanisms and can aggravate agency problems, especially under the unique two-tier board system in China.

Fourth, how the equity incentives of the supervisory board affect corporate fraud has not been studied before. There is a common view that supervisory boards of Chinese-listed firms are not effective. The literature has examined the role of the board in deterring corporate fraud, and found mixed results (Jia et al., 2009). However, the question that we examine here is: are supervisors' equity incentives leading to better monitoring of management, or are they providing incentives to cooperate with management for their own benefit (e.g., poorer monitoring) in the form of inflated stockholdings?

The remainder of this paper is organized as follows. In section 2, we discuss previous literature and we develop testable hypotheses. We cover sample selection and describe our variables in section 3. In section 4, we explain our research design, and in section 5, we report our results. Finally, section 6 concludes.

\section{Previous literature and hypotheses development}


Executive compensation, equity incentives, and corporate fraud

The unique ownership structure and corporate governance of Chinese-listed firms have an effect on executive pay practices (Firth et al., 2006, 2007a). ${ }^{3}$ Despite the significant differences between China and the U.S., Conyon and He (2011) have found that compensation practices in both countries share many similarities. For example, they find that firm size and performance are the main drivers of executive pay in China, likewise in the U.S. However, executive compensation in the West has also been linked to fraudulent behavior (e.g., Harris and Bromiely, 2007).

Conyon and $\mathrm{He}$ (2014) study the consequences of corporate fraud on executive compensation in China. They show that the "fixed" part of executive compensation (e.g., base salary, bonus, and stipends) tends to decrease after the announcement of an enforcement action by the China Securities Regulatory Commission (CSRC). Other studies analyzing the determinants of corporate fraud have highlighted the importance of corporate oversight and ownership (Chen et al., 2006; Hou and Moore, 2010; Firth et al., 2011). Yet, none of these studies have explored the effect of equity incentives in the form of executive stockholdings on corporate fraud.

Stock-based compensation has become increasingly important in Chinese firms. ${ }^{4}$ Several studies claim that Chinese-listed firms have been encouraged to adopt Western management practices with respect to discipline and incentives (Firth et al., 2007a; Bryson et al., 2014). ${ }^{5}$ However, equity-based compensation is generally believed to better align the interests of 
managers and shareholders, although, in certain circumstances, it may also motivate management to engage in fraudulent activities.

Equity incentives are designed to align the interests of a risk-averse manager with those of diversified shareholders in order to ensure the manager will undertake all positive net present value risky projects (Jensen and Meckling, 1976). Yet, it is argued that performance-based incentives can also induce managers to misreport performance, because they may benefit from the upside potential of increased stock price. Bar-Gill and Bebchuk (2003) show that managers may also have incentives to misreport performance, irrespective of the vesting period. For example, if they are not yet able to sell shares, they may misreport to decrease the cost of capital.

Goldman and Slezak (2006) argue that the optimal pay-for-performance sensitivity, maximizing firm value, is a trade-off between the benefits arising from managerial effort and the cost of inflating firm performance. Their model implies that pay-for-performance sensitivity increases the possibility of manipulation. Similarly, Peng and Roell (2008b) assert that performance-based compensation induces both managerial effort and manipulation.

Thus, the theoretical literature states that fraud can be induced by performance-based compensation. However, note that, despite the large branch of empirical literature that examines how equity incentives affect corporate fraud, overall results are mixed. For example, Erickson et al. (2006) find no evidence that equity incentives are associated with fraud. Similarly, Armstrong et al. (2010) show that accounting manipulation is less likely in firms where CEOs have high equity incentives.

In contrast, Burns and Kedia (2006) show that the sensitivity of a CEO's option portfolio to stock prices is positively correlated with financial report restatements. Bergstresser and Philippon (2006) show that CEOs are more likely to manipulate reported earnings when granted 
high equity incentives. Denis et al. (2006) assert a significantly positive link between the likelihood of fraud allegations and stock option intensity, while Harris and Bromiley (2007) find empirical support for the notion that both CEO incentives and performance relative to peers can influence financial statement misrepresentation. Moreover, Peng and Roell (2008a) find that incentive pay in the form of options increases the likelihood of securities class action litigation. Johnson et al. (2009) add to this evidence by showing that firms committing fraud tend to offer greater stock incentives. Armstrong et al. (2013) show that equity incentives are positively correlated with misreporting when managers' wealth is tied to their equity risk.

Much of the earlier literature focused on CEOs' equity incentives. But several recent papers have analyzed the equity incentives granted to CFOs, and how they impact the likelihood of fraud. For example, Feng et al. (2011) find that CFOs with higher performance-based pay are more likely to commit fraud. However, their motivation is not to increase wealth, but is rather due to pressure from their CEOs. Jiang et al. (2010) also show that financial manipulations are more sensitive to CFO equity-based pay than to CEO equity-based pay.

Thus, although there is a rich set of theoretical and empirical studies on equity incentives and corporate fraud, the evidence remains inconclusive. The differing findings may be attributable to differences in equity incentive measures, sample periods, or research designs. The literature also offers a vivid debate on how to measure equity incentives. Early studies have used stockholding or option intensities to proxy for equity incentives. Later studies argue that fraud is related to a manager's portfolio sensitivity to stock prices (portfolio delta), while others have found that sensitivity to stock volatility (portfolio vega) is the appropriate incentive measure.

Furthermore, the measures of fraudulent behavior also differ. Some studies focus on litigation and regulatory enforcement actions, while others concentrate on restatements or 
earnings management. The results can also be sensitive to the econometric specification used, i.e., matching versus regression. Lastly, most of the papers examine data for Western economies. Emerging countries like China, with its unique ownership structure and corporate governance, remain relatively unexplored. Therefore, the focus of this paper is to examine the relationship between equity incentives and corporate fraud in China.

The literature cited above suggests that implementation of equity incentives must ensure a balance between the positive and negative consequences. Performance-based components may provide incentives to risk-averse managers to take on riskier investment projects, but they may also increase the likelihood of corporate fraud. This notion is based on the fact that fraudulent behavior may inflate stock prices, and thus the value of managers' stockholdings as well. Managers may profit from fraud by selling their shares at inflated prices. Johnson et al. (2009) show that executives tend to sell more shares during periods of fraud than during normal periods. Managers whose wealth is the most sensitive to stock price changes can benefit the most from fraudulent behavior.

This is in line with Becker (1968) and Fischer and Verrecchia (2000), who suggest that agents commit fraud only if the benefits exceed the cost of getting caught and punished. If the latter is lower than the wealth increase, the individual will have a stronger incentive to engage in fraudulent activities. China is a developing country with institutions and a legal environment that have lagged behind the rapid development of its financial markets (Chen et al., 2005). Therefore, the expected cost of being caught and punished is likely to be relatively low. We thus hypothesize that managers may wish to affect investor perceptions of their company, and hence their stock prices. Therefore, our main hypothesis is to expect that management equity incentives will enhance corporate fraud. 
H1 The effect of management equity incentives on corporate fraud is positive.

Corporate governance of Chinese-listed firms

Despite the major regulatory shifts toward Western standards, the institutional setting and corporate governance mechanisms in China remain quite different than those in other countries. For example, Chinese companies have a specific governance system that incorporates features of both a U.S.-style single board and a German-style two-tier board. They thus have both a board of directors and a supervisory board (Jia et al., 2009).

The board of director's main responsibilities are fairly similar to those of its U.S. counterpart (Cho and Rui, 2009). Its main role is to define and supervise long-term investment strategies. It also decides on executive compensation. Board characteristics such as directors' independence have been found to affect pay-for-performance sensitivity (Conyon and $\mathrm{He}, 2011$ ).

The role of the supervisory board, on the other hand, is to monitor management, the board of directors, and to oversee the firm's financial affairs. The members of the supervisory board (supervisors) have access to information about the company's operations. However, in contrast to management and the board of directors, they have no decision making power (Xi, 2006).

In general, certain board characteristics have a stronger influence on the incidence of fraud, such as, for example, size, independence, and CEO duality. Board size may have a double effect on monitoring. On the one hand, larger boards should have a better knowledge base (Karamanou and Vafeas, 2005); on the other hand, sizable boards are more costly and may be 
less effective at oversight (Jensen, 1993; Yermack, 1996). Dechow et al. (1996) show that weak corporate governance mechanisms can create an environment of increased opportunities for fraud.

In China, the state has the authority to appoint both board and supervisory members (Conyon and He, 2011). Theoretically, this should weaken its monitoring role. Chen et al. (2006) show that the presence of outside directors on the board helps to mitigate fraudulent activities in China. They also show that firms with CEO duality (where one individual holds both the CEO and chairman positions) tend to have higher incidences of fraud. ${ }^{6}$

Moreover, individuals at various levels of the corporate hierarchy may have fundamentally different incentives to commit fraud. The triangle theory suggests that fraud can occur if individuals have 1) opportunity, 2) attitude, and 3) incentives, or feel pressured (Cressey, 1950; Trompeter et al., 2012). We therefore distinguish among the various shareholding groups in a company to gauge each group's trade-off between the benefits of committing fraud and the cost of getting caught and punished. Some argue that supervisors should be empowered to take legal action against company management if they detect misconduct (Xi, 2006). However, little is known about whether equity holdings of boards affect corporate fraud. We thus analyze the incentives to engage in fraudulent activities that may stem from supervisory board stockholdings.

There is some tension in the literature over the efficacy of the supervisory board. For example, Xi (2006) reports that supervisory boards are perceived as dysfunctional in their monitoring roles. Other studies, however, show the opposite. Supervisory boards have the ability to improve the quality of accounting information in Chinese firms (Firth et al., 2007b; Cho and Rui, 2009). 
Jia et al. (2009) also report that supervisory boards can serve as an active corporate governance mechanism. In fact, as Dahya et al. (2003) show, investors value the supervisory board report within financial statements, which implies that they also value the monitoring role performed by supervisors. Supervisory board members act as watchdogs, and have fewer incentives to engage in fraudulent activities. Therefore, the effect of supervisory board member shareholdings on corporate fraud should be negative.

H2 The effect of supervisory board equity incentives on corporate fraud is negative.

Ownership structure of Chinese-listed firms: SOEs and non-SOEs

The ownership of Chinese companies is quite concentrated. In particular, the major blockholders still tend to be state institutions. State ownership in turn affects the information environment of public firms (Gul et al., 2010), as well as the monitoring functions of the board and external investors.

More than half of Chinese-listed firms are state-owned. The impact of state ownership on the relationship between equity incentives and corporate fraud has not yet been studied. However, SOEs differ along many dimensions from non-SOEs in ways that may affect the monitoring mechanisms and the cost-benefit analysis of management to engage in fraudulent behavior. The various elements of state ownership can increase the incentives and create more opportunities to commit corporate fraud.

First, SOE management has little influence over firm performance. SOEs are governed by the State-Owned Assets Supervision and Administration Commission (SASAC), which acts as a 
board of directors, evaluating management performance and approving investment projects. Furthermore, performance evaluations, salary increases, and career advancement in SOEs often depend on political connections and the rank of the SOE (Du et al., 2012; Hass et al., 2014). SOE management also has very little power to maximize firm value or affect stockholdings. The state influences all of a firm's important decisions. Therefore, SOE management may have higher incentives to engage in corporate fraud because it is the only direct method by which they can affect stock prices.

Second, state ownership may affect both internal and external corporate governance mechanisms by affecting the information environment of public firms. SOEs are believed to have weaker investor protections and more opaque financial disclosures (Shleifer and Vishny, 1994). Gul et al. (2010) show in a Chinese context that the information environment of firms tends to be poorer when the largest shareholder is government-related. Therefore, a poor information environment combined with deficiencies in monitoring may lead to a situation where management has more opportunities to commit corporate fraud.

Third, regulations in the Chinese system are not always enforced consistently, and the consequences of committing fraud in an SOE context tend to be less severe. Hou and Moore (2010) suggest that fraud detection differs between SOEs and non-SOEs due to political connections. They show that SOEs face less scrutiny from enforcement authorities. Moreover, Chen et al. (2011) show that punishment for committing corporate fraud in SOEs is less severe and tends to be more delayed. Conyon and $\mathrm{He}$ (2014) find that reductions in compensation and management turnover in SOEs are both lower. This implies that the relative expected cost of committing corporate fraud in SOEs is lower than for non-SOEs. 
Based on the above arguments, we expect that SOE management is more constrained from affecting stock prices and their wealth from stockholdings through performance improvement. Also, the expected costs of committing fraud are expected to be lower in SOEs because of a lower rate of detection and less severe consequences. Hence, we hypothesize that, if SOE managers wish to increase their own wealth through stockholdings, they may have stronger incentives and more opportunities to engage in fraudulent activities than their non-SOE counterparts.

H3 The effect of management equity incentives on corporate fraud is more pronounced in SOEs than in non-SOEs.

\section{Sample selection and variable descriptions}

Sample

To analyze how equity incentives affect corporate fraud, we use data from the China Stock Market and Accounting Research (CSMAR) database. CSMAR contains detailed information on the regulatory enforcement actions against corporate fraud in Chinese-listed firms, as well as corporate governance mechanisms, analyst forecasts, financial data, and trading information for listed firms on both the Shanghai and Shenzhen stock exchanges. The data come directly from public firms' annual financial reports and from major CSRC announcements, and have also been used in previous studies on executive compensation and corporate fraud (e.g., Firth et al., 2006, 2007a; and Conyon and He, 2011, 2014). 
We note that it can be difficult to precisely measure corporate fraud. Our sample of fraud firms comes from the CSRC Enforcement Actions Research Database. It consists of firms listed on both exchanges that were subject to enforcement actions by the CSRC and regulatory authorities from 2000-2010. The potential limitation of this and previous studies is that the detected and disclosed fraud is only a small subset of total fraud. Furthermore, in the specific context of China, fraud detection as we noted may be lower in SOEs than in non-SOEs because of political motivations (Hou and Moore, 2010). However, this effect should be mitigated by the introduction of the new "Solutions for Listed Firms Checks" regulation in 2001 that increased the general severity of the regulatory environment (Hou and Moore, 2010).

Overall, our sample consists of 309 firms that faced enforcement actions by regulatory institutions. Note that firms can face enforcement actions for reasons that are not attributable to firm management. We therefore follow prior literature (e.g., Armstrong et al., 2010), and include only cases involving inflated profits, asset fabrications, disclosure postponements, false statements, major failures in information disclosures, and only those where the object of punishment was management, the firm, or both. We exclude cases of illegal share buybacks, major shareholder embezzlement, price manipulation, fraudulent listings, illegal guarantees, and illegal speculation.

We count enforcement actions against the same firm, management, or both, and within the same year, as one observation. However, a particular fraud can occur over several years. We therefore follow Peng and Roell (2008a) and use a stricter definition of fraud. We set our indicator variable Fraud to 1 only for the year that the fraudulent activity began.

We first compare the incentives of management and supervisors resulting from stockholdings and cash compensation in fraud firms to matched non-fraud firms with similar 
metrics based on firm size for each year and industry pair. We test the effect of equity incentives on the likelihood of corporate fraud by controlling for ownership characteristics, corporate governance, and firm characteristics. We obtain data on: 1) all firms from the CSMAR China Stock Market Financial Statements Database, 2) external corporate governance from the CSMAR China Listed Firm's Corporate Governance Research Database, and 3) stock market information from the CSMAR China Stock Market Trading Database. Further details on variable definitions and data sources are in Appendix A.

Incentive Measurement

Executive compensation typically consists of a fixed part in the form of cash and performancebased pay that may include 1) an incentive component to align future salary increases with firm performance, or 2) equity-based incentives that can be granted in various forms contingent on a firm's stock. Our primary goal is to examine how the equity incentives of management and the supervisory board affect corporate fraud.

Equity incentives are usually calculated as pay-performance sensitivities, so that the compensation package is somewhat dependent on firm performance. Furthermore, to measure incentives, it is generally accepted to compute a $\$ 1$ change in the portfolio, including executive stock or option values, for a $1 \%$ change in stock price (Core and Guay, 2002; Erickson et al., 2006).

As we noted earlier, in China, the details of performance-based compensation have been disclosed since 2005 . However, currently available data suggest that most incentive plans have not yet been fully implemented, so we use a different proxy to measure equity incentives. The 
Securities Act 1999 (Article 61) required Chinese-listed firms to disclose the resumes of all directors, supervisors, and top managers, along with their shareholdings in the company, in their annual reports (Li et al., 2013). Due to the inherent data limitations, we use these stockholdings as the measure of equity incentives. Following Cheng and Warfield (2005) and Aggarwal (2007), we measure equity incentives as explicit pay-to-performance sensitivities from stockholdings; in particular, we take the stockholdings as a fraction of the total equity outstanding.

To proxy for the equity incentives of supervisors and management, we use the following variables: 1) the supervisors' share (the number of shares held by the Board of Supervisors, including the Chairman, over total equity), and 2) management's share (the number of shares held by management, including the general manager, the president, CEO, assistant general manager, the vice president, secretary to the board of directors, and other directors, over total equity).

\section{Control Variables}

Besides the main independent variables, in order to control for the fixed part of executive compensation in a form of cash, we include the sum of the total annual salaries of the directors, supervisors, and executives. We also include internal and external corporate governance measures and firm characteristics.

To control for various characteristics of the internal corporate governance mechanisms, we use the following variables. Supervisory Board Size and Board Size capture the number of board members (Chen et al., 2006). Independent represents the number of independent directors as a fraction of all directors (Beasley, 1996; Cornett et al., 2008). Dual Role is an indicator 
variable equal to 1 if an individual holds the $\mathrm{CEO}$ and chairperson positions simultaneously, and 0 otherwise (Efendi et al., 2007; Johnson et al., 2009). Ownership is the Herfindahl Index of ownership concentration that is calculated as the sum of the squared percentage of shares owned by the top ten shareholders (Jia et al., 2009). We use Number of Analysts to proxy for the external oversight of a firm (Cumming et al., 2011).

We also include firm characteristics in our regression. To control for a firm's growth opportunities, we use Market-to-Book. We include Leverage to represent total long-term debt over total assets. As a company performance measure, we use Return on Assets (RoA), and we control for the possibility of rent extraction. Following Dechow et al. (1996), we calculate the variable Free-Cash-Flow. Then, following Erickson et al. (2006), we use Altman's (1968) Zscore measure to proxy for the risk of financial distress. We also include Firm Size, which is the logarithm of total market value.

Ndofor et al. (2013) find that information asymmetries arising from industry- and firmlevel complexities increase the probability of top managers committing financial reporting fraud. Thus, each regression model also contains a set of industry fixed-effects variables to capture industry variations. We base each industry classification on the CSRC's industry classification codes. Finally, we include a set of time dummies to capture year effects. The definition and source of the variables used in the analysis are in Appendix A.

\section{Research design}

Our research design follows prior research. We first examine the effect of equity incentives on corporate fraud based on matched-sample and regression analyses. We follow previous studies 
such as Erickson et al. (2006), Efendi et al. (2007), Jia et al. (2009), Hou and Moore (2010), and Armstrong et al. (2013) to create a matched-sample based on an outcome-based matching procedure. In particular, we form matched pairs of fraud to non-fraud firms based on industry and firm size. For every fraud firm, we find a non-fraud firm in the same industry that is closest in size, where all variables are measured in the year before the fraud was committed. This design allows us to compare fraudulent activities between fraud and non-fraud firms with similar characteristics. Next, to perform our regression analysis, we estimate the following logistic model:

$$
\text { Fraud }_{i, t}=\alpha_{i, t}+\boldsymbol{\theta} \text { Incentives }_{i, t-1}+\boldsymbol{\beta} \text { Controls }_{i, t-1}+\text { Industry } F E+\text { Year } F E+\varepsilon_{i, t}
$$

where Fraud is a dummy variable that equals 1 for the first year a firm engaged in a fraud that was subject to a regulatory enforcement, and 0 otherwise, Incentives is a vector of variables related to the components of compensation cash, supervisor shares, and management shares, Controls is a vector of control variables, including those in both internal and external corporate governance and firm-level characteristics (all defined in the Appendix). We adjust standard errors to compute statistical significance for heteroscedasticity.

\section{Results}

Descriptive statistics 
Table 1 presents the descriptive statistics for the matched sample of firms in panel A. Panel B breaks down our sample between fraud and non-fraud firms. Panel C gives a breakdown by SOE and non-SOE.

We first provide some information about the size and composition of compensation for management and supervisors. Management is paid on average a fixed salary of U.S. \$1.3 million. If we examine their equity incentives in more detail, we find that management holds on average $0.88 \%$ of shares, which is equal to U.S. $\$ 3.9$ million. In comparison, supervisors hold only $0.06 \%$ of shares, which are worth approximately U.S. $\$ 0.2$ million. Therefore, equity incentives form a major part of management's total compensation, but only a very small part of supervisor compensation.

Panel B shows the descriptive statistics separately for fraud and non-fraud firms, matched by size and industry. We find that fraud firm management tends to have higher equity incentives than the matched non-fraud firm management. However, non-fraud firm supervisors have higher equity incentives than those of fraud firms. Finally, as panel $\mathrm{C}$ of Table 1 shows, SOEs are fundamentally different than non-SOEs in our sample.

[Please insert Table 1 here]

Table 2 shows the correlation matrix for the main variables used in our study. Note that fraud exhibits a significantly negative correlation with cash payments. However, the percentage of shares held by management has a significantly positive correlation with corporate fraud activities. Among other things, the fraction of independent directors, leverage, and firm size are all statistically negatively correlated with corporate fraud activities. 
[Please insert Table 2 here]

Overall, the correlations highlight the fact that the impact of different compensation components for individuals at different levels of the corporate hierarchy can vary tremendously. A comparison between SOEs and non-SOEs also shows significant differences between these two types of firms. SOE directors, supervisors, and executives tend to have a smaller cash component to their compensation and less equity compensation than non-SOEs (which is consistent with Conyon and He, 2011). Nevertheless, these tests are not fully informative, because we have not yet controlled for other factors. The next section describes our multivariate analyzes in more detail.

Empirical analyses

In this section, we explore the empirical results for our different models. First, Table 3 presents the empirical results for the matched sample of firms. ${ }^{7}$ We then divide it into two subsamples: SOEs (Table 4) and non-SOEs (Table 5). Furthermore, we present additional results of the sensitivity analysis (Table 6), and the results for the full sample (Table 7).

Table 3 reports the results from a panel logistic regression for the relationship between equity incentives and corporate fraud for the matched sample of firms. In model 1, we show separately the relationship between cash and management equity incentives and the propensity to commit fraud. In models 2 and 3, we test the effect of cash and performance-based incentives of management on corporate fraud while controlling for corporate governance mechanisms and 
firm characteristics, respectively. In models 4 and 5, we examine the link between cash and the shareholdings of the supervisory board and management and fraud, while controlling for corporate governance and firm characteristics, respectively. Model 6 shows the relationship between the fixed and equity-based components and fraud, while controlling simultaneously for corporate governance and firm characteristics.

Table 3 shows that higher equity incentives for management lead to a higher propensity to commit corporate fraud, which is consistent with our Hypothesis 1. This holds across all our models. Equity incentives are also economically significant. A 1-standard-deviation increase in equity incentives for managers increases the likelihood of fraud activity by $2.78 \%-3.09 \%$. We also find that cash compensation has a negative and statistically significant effect on the probability of committing corporate fraud. A higher fixed salary reduces the incentives to commit fraud, which is in line with theoretical predictions. We find no evidence that the equity incentives of supervisors affect the propensity to commit fraud, however. But we cannot gauge whether this is due to more limited opportunities to commit fraud, or to the relatively small absolute value of the incentives. Note that certain governance characteristics, such as larger supervisory boards and more concentrated ownership, can serve to deter incidences of corporate fraud.

[Please insert Table 3 here]

Our comparison results in panel $\mathrm{C}$ of Table 1 indicate that SOEs and non-SOEs differ dramatically in terms of corporate governance and firm characteristics. We therefore divide our sample by SOEs (Table 4) and non-SOEs (Table 5). The result indicates that the relationship 
between the equity incentives of managers and the propensity to commit corporate fraud is stronger in SOEs, which is in line with our prediction in Hypothesis 3. Using overall average shareholdings by managers, we find that a 1-standard deviation increase in equity incentives for SOE managers increases the likelihood of fraud by $3.34 \%-3.99 \%$, compared to only $2.13 \%$ $2.51 \%$ for non-SOE managers. Again, we find no evidence that higher supervisor equity incentives increase the propensity to commit fraud. Also, the effects of corporate governance characteristics are similar for both SOEs and non-SOEs.

[Please insert Table 4 and Table 5 here]

Robustness tests

Table 6 presents additional robustness tests for our matched sample. In model 1, we include the number of analysts as an additional control variable to proxy for external corporate governance. We find weak evidence that it deters corporate fraud and that the economic effect of management shareholdings on corporate fraud is lower. Therefore, it may partially support Cumming et al. (2011) finding that analysts are efficient at mitigating corporate fraud.

Model 2 presents the results with a High Litigation Risk (HLR) dummy variable, which equals 1 if the firm is in the computer or a related manufacturing, medical manufacturing, chemical, or retail industry (Kim and Skinner, 2012). In these industries, supervisory boards have been particularly effective at curbing fraud.

Models 3 and 4 give the results for subsamples based on firm size. Consistent with our previous results, we note that the magnitude of the effect of management shareholdings on 
corporate fraud is larger in smaller firms. We also observe that the boards of directors in larger firms may not be as efficient in their monitoring role as those in smaller firms.

Models 5 and 6 present the results for subsamples based on supervisory board size. Interestingly, our results suggest that supervisory boards with more than four members are very effective in their monitoring role.

Model 7 shows our results for using a stricter definition of the Fraud dummy, where we only include the first fraud a company has committed. We also find a positive and statistically significant effect of management shareholdings on corporate fraud.

Models 8 and 9 present the results for the subsamples before and after the 2005 split share reform. Prior to the 2005 reform, the shares of SOEs were typically non-tradable. In 2005, Chinese authorities announced the elimination of non-tradable shares by the end of 2006 (Hou et al., 2013). Cumming et al. (2012) report that this reform had an effect on the incentives of managers to misreport performance. After the reform, they find that CEO turnover following corporate fraud disclosures increased. We find that, before the reform, the effect of management shareholdings was insignificant. This effect may be driven by the fact that SOE shares were nontradable before the split-share reform, so management had less of an incentive to misreport performance because their wealth was fixed. When the SOE shares became tradable after the reform, we find a significant and statistically significant effect of management shareholdings on corporate fraud.

Giroud and Mueller $(2010,2011)$ claim that product market competition can act as an external corporate governance mechanism. Models 10 and 11 present the results for the subsamples of firms operating in concentrated and competitive industries, respectively. We define the industry concentration based on the Herfindahl Hirschman Competition Index (HHI), 
where HHI (Low) and HHI (High) mean that HHI is greater/equal than median value and less than the median value. HHI (High) means that $\mathrm{HHI}$ is greater/equal than the median value and less than the median value. Equity incentives have a significantly positive effect on corporate fraud in both competitive and non-competitive industries. We also find that the equity incentive of supervisors decreases the probability of corporate fraud, but only in non-competitive industries. This provides support for the argument that corporate governance is of greater consequence in non-competitive markets.

There are differences in economic and institutional development across regions in China. Firth et al. (2011) report that coastal regions are more developed than the western and inland provinces. They point out that the view of ethics, law system, and executives experience might differ across regions. Therefore, the incentives and the expected cost of committing corporate fraud might depend on where the firm is located. Managers of firm located in low development regions might face lower expected costs of being punished due to weak institutional and legal system.

We use and index of regional development that measures market intermediaries and legal environment (MLS). Models 12 and 13 show the results for the subsamples of firms operating in regions with different development. Model 12 presents the results for regions with higher market and legal development, where MLS > 5.5, i.e. above the median value of the MLS index. Model 13 presents the results for regions with lower market and legal development, where MLS $<=5.5$. We find that the relationship between equity incentives and corporate fraud is more pronounced in less developed regions. This supports the intuition that the expected costs of committing corporate fraud might be lower in less developed regions. 
[Please insert Table 6 here]

Table 7 shows the results of additional robustness tests for the unmatched sample. The results are similar to those for the matched sample. They confirm the previously documented result of a positive and statistically significant effect of management stockholdings. In the unmatched sample, we also find a negative and statistically significant effect of cash pay on corporate fraud. Furthermore, our results confirm that firm size and the debt ratio lower the probability of committing corporate fraud, as well as the importance of supervisory board and ownership concentration in mitigating corporate fraud for the full and SOE sample.

[Please insert Table 7 here]

\section{Discussion and conclusion}

The Chinese economy has experienced unprecedented growth and the rapid development of financial markets. However, the future growth and viability of Chinese-listed firms may be overshadowed by corporate fraud. Chinese regulatory authorities are charged with monitoring the economy, and they regularly update reporting standards in order to improve transparency and prevent fraud. However, fraud may also be a byproduct of the introduction of performance-based compensation packages, which were previously more common in Western economies. Chinese companies have become increasingly more Western-oriented in setting compensation packages and in using incentive-based components. Although stock options were not permitted until 2006, 
Chinese companies had other incentives in the form of bonuses and stockholdings that have grown in importance over time.

The academic literature suggests that if higher incentives are granted to executives, the effect may be twofold: 1) a positive effect in terms of aligning the interest and risk profile of managers and shareholders, and 2) a negative effect in terms of managerial behavior, which can lead to an increased propensity to commit corporate fraud. Moreover, corporate scandals in the West (e.g., Enron, WorldCom) have shown that increased incidences of fraudulent accounting disclosures may occur in cultures driven by stock price performance.

Following this wave of corporate scandals, Western regulators introduced severe penalties for fraudulent behavior. However, there is an ongoing and dynamic discussion of whether stricter regulations actually achieve the desired goal. Bar-Gill and Bebchuk (2003) report that lax accounting and legal environments can increase the incidence of misreporting and consequently distortions in capital allocations. Goldman and Slezak's (2006) model implies that, if the penalty for manipulation is increased, it may actually induce corporate fraud, because corporate monitoring may become less vigilant in light of more complex regulating policies.

However, Chinese authorities have generally tried to encourage incentive-based compensation. For example, the Code of Corporate Governance for listed firms in China (CSRS 2002, article 18, chapter 2) stipulates that management should be chosen competitively, and that compensation should include incentive pay. Nonetheless, the important question for the Chinese economy is whether equity incentives should be promoted to the extent that they are in, e.g., Western economies, where they have been identified as potential causes of corporate fraud.

In light of corporate fraud in China, our main goal here was to examine whether equity incentives enhance the incidence of corporate fraud in Chinese-listed firms. Although the data on 
incentives and their impact are somewhat limited, we use various proxies to measure incentives such as cash and management and supervisory board shareholdings. Our main findings suggest a clear and robust pattern of a positive and statistically significant effect of management equity incentives on corporate fraud. Note, however, that the magnitude of the effect is higher in SOEs than in non-SOEs. Therefore, it may be more desirable to encourage private ownership of Chinese firms. We do not find any strong association between equity incentives and corporate fraud for supervisory board members.

Given that the importance of performance-based incentives has grown gradually in China, we believe future research should pay particular attention to the individual incentives of various management team members, such as, e.g., the $\mathrm{CEO}$ or the $\mathrm{CFO}$, and attempt to verify whether the causes of corporate fraud are related to performance-based compensation on the various levels of the corporate hierarchy.

Acknowledgements: The authors gratefully acknowledge valuable feedback from the guest editors, Douglas Cumming, Wenxuan Hou, Edward Lee, two anonymous referees, Oliver Rui (discussant), participants at the Conference on Business Ethics in Greater China: Past, Present and Future, and seminar participants at the Warsaw School of Economics. 


\section{Appendix}

Table A. Variable Definitions

\begin{tabular}{|c|c|}
\hline Variable Name & Definition [Source] \\
\hline Fraud & $\begin{array}{l}\text { A dummy variable equals to } 1 \text { for the year of a firm is subject to a } \\
\text { regulatory enforcement against fraud, and } 0 \text { otherwise [CSRC's } \\
\text { Enforcement Actions Research Database] }\end{array}$ \\
\hline Cash & $\begin{array}{l}\text { Log of total annual emolument of directors, supervisors and } \\
\text { executives [China Listed Firm's Corporate Governance Research } \\
\text { Database] }\end{array}$ \\
\hline Supervisors & Percentage of shares held by board of supervisors [China Listed Firm's \\
\hline Share $(\%)$ & Corporate Governance Research Database] \\
\hline Management & Percentage of shares held by management [China Listed Firm's \\
\hline Shares $(\%)$ & Corporate Governance Research Database] \\
\hline Supe & Total number of supervisors [China Listed Firm's Corporate \\
\hline Boar & Governance Research Database] \\
\hline Board Size & $\begin{array}{l}\text { Total number of directors [China Listed Firm's Corporate Governance } \\
\text { Research Database] }\end{array}$ \\
\hline $\begin{array}{l}\text { Independent } \\
(\%)\end{array}$ & $\begin{array}{l}\text { Percentage of independent directors as fraction of number of } \\
\text { independent directors divided by number of total board members } \\
\text { [China Listed Firm's Corporate Governance Research Database] }\end{array}$ \\
\hline Dual Role & $\begin{array}{l}\text { A dummy equals } 1 \text { if the firms' CEO and the board chairman are not } \\
\text { the same person and } 0 \text { otherwise [China Listed Firm's Corporate } \\
\text { Governance Research Database] }\end{array}$ \\
\hline Ownership & $\begin{array}{l}\text { Herfindahl index of ownership concentration is calculated as the sum } \\
\text { of squared percentage of shares owned by the top } 10 \text { shareholders } \\
\text { [China Listed Firm's Corporate Governance Research Database] }\end{array}$ \\
\hline $\begin{array}{l}\text { Number of } \\
\text { Analysts }\end{array}$ & $\begin{array}{l}\text { The number of financial analysts following the firm [China Stock } \\
\text { Market Financial Database] }\end{array}$ \\
\hline t-to- & The market value of the company over book value [CSMAR China \\
\hline Book & $\begin{array}{l}\text { Stock Market Financial Statements Database and CSMAR China } \\
\text { Stock Market Trading Database] }\end{array}$ \\
\hline Leverage & $\begin{array}{l}\text { Total long-term debt over total asset [CSMAR China Stock Market } \\
\text { Financial Statements Database] }\end{array}$ \\
\hline RoA & $\begin{array}{l}\text { Return on asset [CSMAR China Stock Market Financial Statements } \\
\text { Database] }\end{array}$ \\
\hline $\begin{array}{l}\text { Free-Cash- } \\
\text { Flow }\end{array}$ & $\begin{array}{l}\text { Measure of company's desire for external financing of Dechow et al. } \\
\text { (1996) [CSMAR China Stock Market Financial Statements Database] }\end{array}$ \\
\hline Zscore & $\begin{array}{l}\text { Altman's (1968) Z-score [CSMAR China Stock Market Financial } \\
\text { Statements Database] }\end{array}$ \\
\hline Firm Size & $\begin{array}{l}\text { Log of total market value at the end of the year [CSMAR China Stock } \\
\text { Market Trading Database] }\end{array}$ \\
\hline
\end{tabular}




\section{Notes}

${ }^{1}$ U.S. evidence shows negative abnormal returns on the announcement day of an enforcement action by the U.S. Securities and Exchange Commission (SEC) (see Feroz et al., 1991; and Dechow et al., 1996). Moreover, Karpoff et al. (2008) estimate that firms can lose, on average, $38 \%$ of their market value as a result of SEC enforcement actions.

${ }^{2}$ www.economist.com. Accessed on December 21, 2013.

${ }^{3}$ For a discussion on the regulatory framework and institutional setting please see Chen et al. (2006).

${ }^{4}$ In 2006, the State-owned Assets Supervision and Administration Commission (SASAC) and the Ministry of Finance (MOF) published the Trial Procedures for the implementation of stockbased incentives in SOEs ( $\mathrm{Li}$ et al., 2013). In 2007, the CSRC updated their regulations and required the disclosure of compensation committee duties, and the implementation of stockbased incentive plans (Li et al., 2013).

${ }^{5}$ See Firth et al. 2006 for a review of executive pay history in China.

6 It is interesting to note that recent empirical evidence suggests external governance mechanisms are important in China. Chen et al. (2014) find that analyst coverage can mitigate instances of fraud in Chinese-listed companies. This effect is particularly important for nonSOEs because they are more dependent, with respect to financing needs, on capital markets than SOEs. Moreover, Chen et al. (2013) report that the presence of auditors can serve as an external governance mechanism that also mitigates the fraudulent behavior of executives. 
${ }^{7}$ We present the results based on the sample matched by industry and size. However, we also matched the sample based on the propensity score method used by Armstrong et al. (2010), and found very similar results. 


\section{References}

Aggarwal, R. K. (2007). Chapter 17 - Executive compensation and incentives, in B. E. Eckbo, ed.: Handbook of Empirical Corporate Finance. pp. 497-538 (Elsevier).

Allen, F., Qian J., \& Qian M. J. (2005). Law, finance, and economic growth in China. Journal of Financial Economics, 77(1), 57-116.

Altman, E. I., (1968). Financial ratios, discriminant analysis and the prediction of corporate bankruptcy. Journal of Finance, 23(4), 589-609.

Armstrong, C. S., Jagolinzer A. D., \& Larcker D. F. (2010). Chief executive officer equity incentives and accounting irregularities. Journal of Accounting Research, 48(2), 225-271.

Armstrong, C. S., Larcker D. F., Ormazabal G., \& Taylor D. J. (2013). The relation between equity incentives and misreporting: The role of risk-taking incentives. Journal of Financial Economics, 109(2), 327-350.

Ball, R. (2009). Market and political/regulatory perspectives on the recent accounting scandals. Journal of Accounting Research, 47(2), 277-323.

Bar-Gill, O., \& Bebchuk L. (2003). Misreporting corporate performance, Harvard Law and Economics Discussion Paper.

Beasley, M. S. (1996). An empirical analysis of the relation between the board of director composition and financial statement fraud. The Accounting Review 71(4), 443-465.

Bergstresser, D., \& Philippon, T. (2006). CEO incentives and earnings management. Journal of Financial Economics, 80(3), 511-529.

Bryson, A., Forth, J., \& Zhou, M. (2014). Same or different? The CEO labour market in China's public listed companies. The Economic Journal, 124, F90-F108.

Burns, N., \& Kedia, S. (2006). The impact of performance-based compensation on misreporting. Journal of Financial Economics, 79(1), 35-67. 
Chen, G., Firth, M., Gao, D. N., \& Rui, O. M. (2005). Is China's securities regulatory agency a toothless tiger? Evidence from enforcement actions. Journal of Accounting and Public Policy, 24(6), 451-488.

Chen, G., Firth, M., Gao, D. N., \& Rui, O. M. (2006). Ownership structure, corporate governance, and fraud: Evidence from China. Journal of Corporate Finance, 12(3), 424448.

Chen, D., Jiang, D., Liang, S., \& Wang, F. (2011). Selective enforcement of regulation. China Journal of Accounting Research, 4(1), 9-27.

Chen, J., Cumming, D., Hou, W., \& Lee, E. (2013). Executive integrity, audit opinion, and fraud in Chinese listed firms. Emerging Markets Review, 15, 72-91.

Chen, J., Cumming, D., Hou, W., \& Lee, E. (2014). Does the external monitoring effect of financial analysts deter corporate fraud in China?. Journal of Business Ethics, Forthcoming.

Cheng, Q., \& Warfield, T. D. (2005). Equity incentives and earnings management. The Accounting Review, 80(2), 441-476.

Cho, S., \& Rui, O. M. (2009). Exploring the effects of China's two-tier board system and ownership structure on firm performance and earnings informativeness. Asia-Pacific Journal of Accounting \& Economics, 16(1), 95-117.

Conyon, M. J., \& He, L. (2011). Executive compensation and corporate governance in China. Journal of Corporate Finance, 17(4), 1158-1175.

Conyon, M. J., \& He, L. (2014). Executive compensation and corporate fraud in China. Journal of Business Ethics, Forthcoming. 
Core, J., \& Guay, W. (2002). Estimating the value of employee stock option portfolios and their sensitivities to price and volatility. Journal of Accounting Research, 40(3), 613-630.

Cornett, M. M., Marcus, A. J., \& Tehranian, H. (2008). Corporate governance and pay-forperformance: The impact of earnings management. Journal of Financial Economics, 87(2), 357-373.

Cressey, D. R. (1950). The criminal violation of financial trust. American Sociological Review, 15(6), 738-743.

Cumming, D. J., Hou, W., \& Lee, E. (2012). Impact of split share structure reform in China on CEO accountability to corporate fraud. Journal of Business Ethics, Forthcoming.

Dahya, J., Karbhari, Y., Xiao, J. Z., \& Yang, M. (2003). The usefulness of the supervisory board report in China. Corporate Governance: An International Review, 11(4), 308-321.

Dechow, P. M., Sloan, R. G., \& Sweeney, A. P. (1996). Causes and consequences of earnings manipulation: An analysis of firms subject to enforcement actions by the SEC. Contemporary Accounting Research, 13(1), 1-36.

Denis, D. J., Hanouna, P., \& Sarin, A. (2006). Is there a dark side to incentive compensation?. Journal of Corporate Finance, 12(3), 467-488.

Du, F., Tang, G., \& Young, S. M. (2012). Influence activities and favoritism in subjective performance evaluation: evidence from Chinese state-owned enterprises. The Accounting Review, 87(5), 1555-1588.

Efendi, J., Srivastava, A., \& Swanson, E. P. (2007). Why do corporate managers misstate financial statements? The role of option compensation and other factors. Journal of Financial Economics, 85(3), 667-708. 
Erickson, M., Hanlon, M., \& Maydew, E. L. (2006). Is there a link between executive equity incentives and accounting fraud?. Journal of Accounting Research, 44(1), 113-143.

Feng, M., Ge, W., Luo, S., \& Shevlin, T. (2011). Why do CFOs become involved in material accounting manipulations?. Journal of Accounting and Economics, 51(1), 21-36.

Feroz, E. H., Park, K. J., \& Pastena, V. (1991). The financial and market effects of the SEC's accounting and auditing enforcement releases. Journal of Accounting Research, 29(Supplement), 107-142.

Firth, M., Fung, P. M., \& Rui, O. M. (2006). Corporate performance and CEO compensation in China. Journal of Corporate Finance, 12(4), 693-714.

Firth, M., Fung, P. M., \& Rui, O. M. (2007). How ownership and corporate governance influence chief executive pay in China's listed firms. Journal of Business Research, 60(7), 776-785.

Firth, M., Fung, P. M., \& Rui, O. M. (2007). Ownership, two-tier board structure, and the informativeness of earnings-Evidence from China. Journal of Accounting and Public Policy, 26(4), 463-496.

Firth, M., Rui, O. M., \& Wu, W. (2011). Cooking the books: Recipes and costs of falsified financial statements in China. Journal of Corporate Finance, 17(2), 371-390.

Fischer, P. E., \& Verrecchia, R. E. (2000). Reporting bias. The Accounting Review, 75(2), 229245.

Giroud, X., \& Mueller, H. M. (2010). Does corporate governance matter in competitive industries?. Journal of Financial Economics, 95(3), 312-331.

Giroud, X., \& Mueller, H. M. (2011). Corporate governance, product market competition, and equity prices. Journal of Finance, 66(2), 563-600. 
Goldman, E., \& Slezak, S. L. (2006). An equilibrium model of incentive contracts in the presence of information manipulation. Journal of Financial Economics, 80(3), 603-626.

Graham, J. R., Li, S., \& Qiu, J. (2008). Corporate misreporting and bank loan contracting. Journal of Financial Economics, 89(1), 44-61.

Gul, F. A., Kim, J. B., \& Qiu, A. A. (2010). Ownership concentration, foreign shareholding, audit quality, and stock price synchronicity: Evidence from China. Journal of Financial Economics, 95(3), 425-442.

Harris, J., \& Bromiley, P. (2007). Incentives to cheat: The influence of executive compensation and firm performance on financial misrepresentation. Organization Science, 18(3), 350367.

Hass, L.H., Johan, S., \& Mueller, M. (2014). The effectiveness of public enforcement: Evidence from the resolution of tunneling in China. Journal of Business Ethics, Forthcoming.

Hou, W., \& Moore, G. (2010). Player and referee roles held jointly: The effect of state ownership on China's regulatory enforcement against fraud. Journal of Business Ethics 95(2), 317-335.

Hou, W., Lee, E., Stathopoulos, K., \& Tong, Z. (2013). Executive compensation and the split share structure reform in China. European Journal of Finance, Forthcoming.

Huang, F., \& Rice, J. (2012). Firm networking and bribery in China: Assessing some potential negative consequences of firm openness. Journal of Business Ethics, 107(4), 533-545.

Jensen, M. C., \& Meckling, W. H. (1976). Theory of the firm: Managerial behavior, agency costs, and ownership structure. Journal of Financial Economics 3(4), 305-360.

Jensen, M. C. (1993). The modern industrial revolution, exit, and the failure of internal control systems. Journal of Finance, 48(3), 831-880. 
Jia, C., Ding, S., Li, Y., \& Wu, Z. (2009). Fraud, enforcement action, and the role of corporate governance: Evidence from China. Journal of Business Ethics, 90(4), 561-576.

Jiang, J. X., Petroni, K. R., \& Wang, I. Y. (2010). CFOs and CEOs: Who have the most influence on earnings management?. Journal of Financial Economics, 96(3), 513-526.

Johnson, S. A., Ryan, H. E., \& Tian, Y. S. (2009). Managerial incentives and corporate fraud: the sources of incentives matter. Review of Finance, 13(1), 115-145.

Karamanou, I., \& Vafeas, N. (2005). The association between corporate boards, audit committees, and management earnings forecasts: An empirical analysis. Journal of Accounting Research, 43(3), 453-486.

Karpoff, J. M., Lee, D. S., \& Martin, G. S. (2008). The cost to firms of cooking the books. Journal of Financial and Quantitative Analysis, 43(3), 581-611.

Kim, I., \& Skinner, D. J. (2012). Measuring securities litigation risk. Journal of Accounting and Economics, 53(1), 290-310.

Li, Y., Lou, F., Wang, J., \& Yuan, H. (2013). A survey of executive compensation contracts in China's listed companies. China Journal of Accounting Research, 6(3), 211-231.

Ndofor, H. A., Wesley, C., \& Priem, R. L. (2013). Providing CEOs with opportunities to cheat the effects of complexity-based information asymmetries on financial reporting fraud. Journal of Management, Forthcoming.

Peng, L., \& Röell, A. (2008a). Executive pay and shareholder litigation. Review of Finance, 12(1), 141-184.

Peng, L., \& Röell, A. (2008b). Manipulation and equity-based compensation. American Economic Review, 98(2), 285-90. 
Shleifer, A., \& Vishny, R. W. (1994). Politicians and firms. Quarterly Journal of Economics, 109(4), 995-1025.

Tian, Q. (2008). Perception of business bribery in China: The impact of moral philosophy. Journal of Business Ethics, 80(3), 437-445.

Trompeter, G. M., Carpenter, T. D., Desai, N., Jones, K. L., \& Riley Jr, R. A. (2012). A synthesis of fraud-related research. Auditing: A Journal of Practice \& Theory, 32(1), 287-321.

Xi, C. (2006). In search of an effective monitoring board model: board reforms and the political economy of corporate law in China. Connecticut Journal of International Law, 22, 1-46.

Yermack, D. (1996). Higher market valuation of companies with a small board of directors. Journal of Financial Economics, 40(2), 185-211. 


\section{Table 1: Summary Statistics}

This table presents summary statistics for all firm-year observations for the matched sample. Our sample period is 2000 to 2010. All variables are defined in the Appendix. ***,**, and * denote statistical significance at the 0.01, 0.05 and 0.1 levels, respectively. Panel A present the summary statistics for the whole sample of fraud and control firms. Panel B presents the summary statistics for fraud firms and non-fraud firms, matched on industry and firm size, and Panel C for SOEs and non-SOEs.

\begin{tabular}{lcccc}
\hline \multicolumn{2}{l}{ Panel A: Industry and size matched sample } & & & \\
\hline Variables & Mean & Std & Median & Number of Obs. \\
\hline Fraud & 0.151 & 0.358 & 0.000 & 5236 \\
Cash & 0.704 & 0.462 & 0.607 & 5236 \\
Supervisors Share (\%) & 0.061 & 0.713 & 0.000 & 5236 \\
Management Shares (\%) & 0.880 & 4.857 & 0.004 & 5236 \\
Supervisor Board Size & 4.039 & 1.309 & 3.000 & 5236 \\
Board Size & 9.267 & 2.172 & 9.000 & 5236 \\
Independent (\%) & 0.147 & 0.082 & 0.176 & 5236 \\
Dual Role & 0.850 & 0.357 & 1.000 & 5196 \\
Ownership & 0.192 & 0.132 & 0.153 & 5236 \\
Market-to-Book & 3.071 & 69.675 & 2.915 & 5236 \\
Leverage & 0.053 & 0.095 & 0.013 & 5236 \\
RoA & -0.435 & 29.669 & 0.023 & 5236 \\
Free-Cash-Flow & -1.393 & 18.621 & -0.551 & 5236 \\
Zscore & 3.861 & 13.335 & 2.528 & 5236 \\
Firm Size & 21.260 & 0.883 & 21.232 & 5236 \\
\hline
\end{tabular}


Table 1: Summary Statistics (continued)

\begin{tabular}{|c|c|c|c|c|c|c|c|}
\hline & & Fraud Fi & & & n-Fraud & $\mathrm{ms}$ & \\
\hline Variables & Mean & Std & $\begin{array}{c}\text { Number of } \\
\text { Obs. }\end{array}$ & Mean & Std & $\begin{array}{c}\text { Number of } \\
\text { Obs. }\end{array}$ & $\begin{array}{c}\text { Difference in } \\
\text { means }\end{array}$ \\
\hline Fraud & 0.302 & 0.459 & 2618 & 0.000 & 0.000 & 2618 & \\
\hline Cash & 0.650 & 0.450 & 2618 & 0.757 & 0.468 & 2618 & $-8.4235^{* * *}$ \\
\hline $\begin{array}{l}\text { Supervisors } \\
\text { Share }(\%)\end{array}$ & 0.054 & 0.842 & 2618 & 0.068 & 0.555 & 2618 & -0.699 \\
\hline $\begin{array}{l}\text { Management } \\
\text { Shares (\%) }\end{array}$ & 0.924 & 6.089 & 2618 & 0.836 & 3.179 & 2618 & 0.656 \\
\hline $\begin{array}{l}\text { Supervisor } \\
\text { Board Size }\end{array}$ & 4.009 & 1.292 & 2618 & 4.070 & 1.325 & 2618 & $-1.669^{*}$ \\
\hline Board Size & 9.186 & 2.227 & 2618 & 9.349 & 2.113 & 2618 & $-2.712 * *$ \\
\hline $\begin{array}{l}\text { Independent } \\
(\%)\end{array}$ & 0.147 & 0.083 & 2618 & 0.148 & 0.081 & 2618 & -0.316 \\
\hline Dual Role & 0.850 & 0.357 & 2596 & 0.849 & 0.358 & 2600 & 0.093 \\
\hline Ownership & 0.177 & 0.127 & 2618 & 0.207 & 0.135 & 2618 & $-8.256 * * *$ \\
\hline Market-to-Book & 2.196 & 97.794 & 2618 & 3.947 & 12.081 & 2618 & -0.909 \\
\hline Leverage & 0.052 & 0.103 & 2618 & 0.054 & 0.087 & 2618 & -0.703 \\
\hline RoA & -0.065 & 1.086 & 2618 & -0.805 & 41.945 & 2618 & 0.903 \\
\hline Free-Cash-Flow & -1.896 & 26.237 & 2618 & -0.889 & 1.924 & 2610 & $-1.955^{*}$ \\
\hline Zscore & 3.220 & 16.074 & 2618 & 4.502 & 9.824 & 2618 & $-3.480 * * *$ \\
\hline Firm Size & 21.263 & 0.873 & 2618 & 21.258 & 0.894 & 2618 & -0.199 \\
\hline
\end{tabular}


Table 1: Summary Statistics (continued)

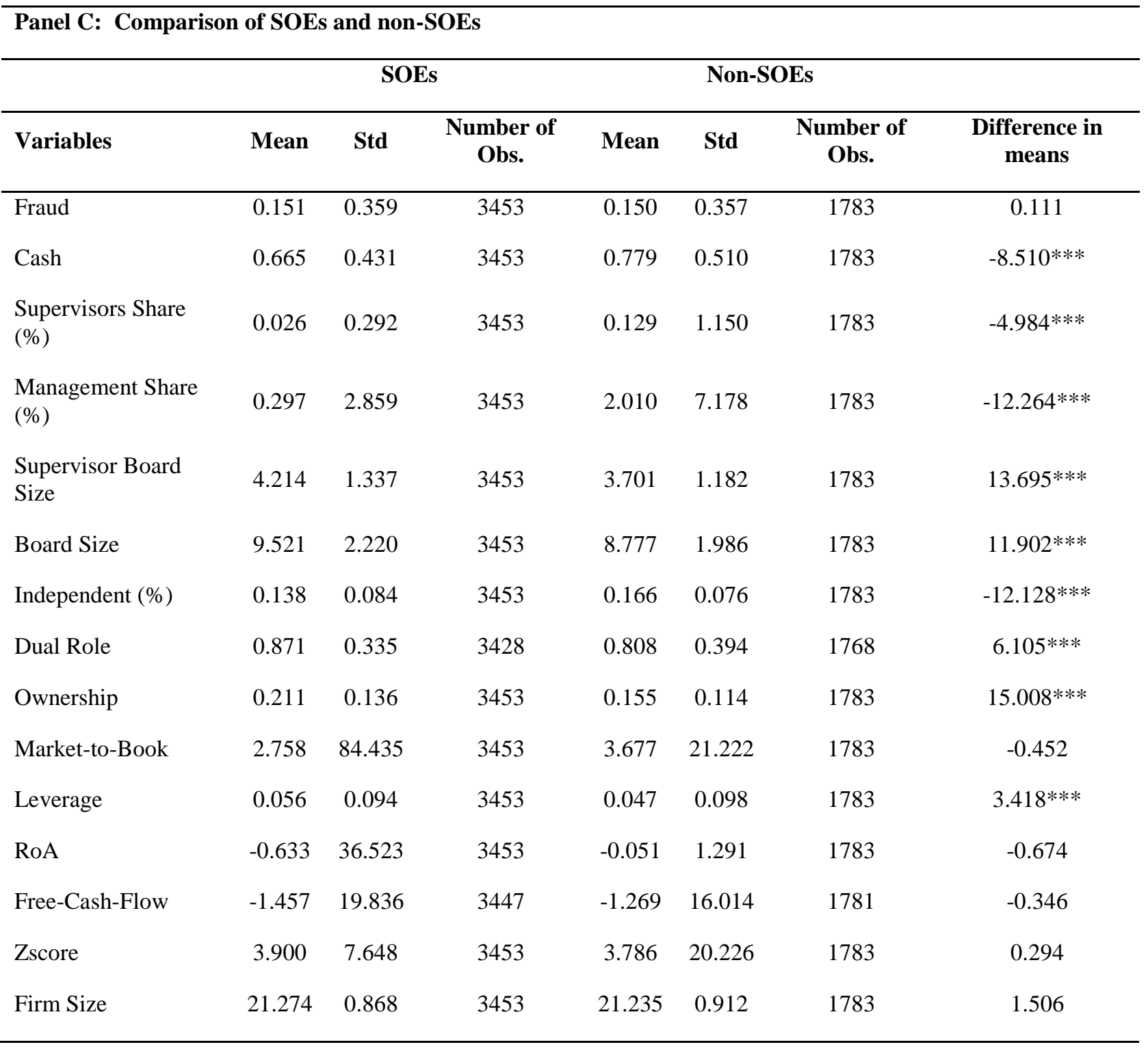




\section{Table 2: Correlation Matrix}

This table presents the correlations of variables in the data. All variables are as defined in the Appendix. $*$ indicates that correlations are statistically significant at least at the $5 \%$ level.

$\begin{array}{lllllllllllll}(1) & (2) & (3) & (4) & (5) & (6) & (7) & (8) & (9) & (10) & (11) & (12) & (13)\end{array}$

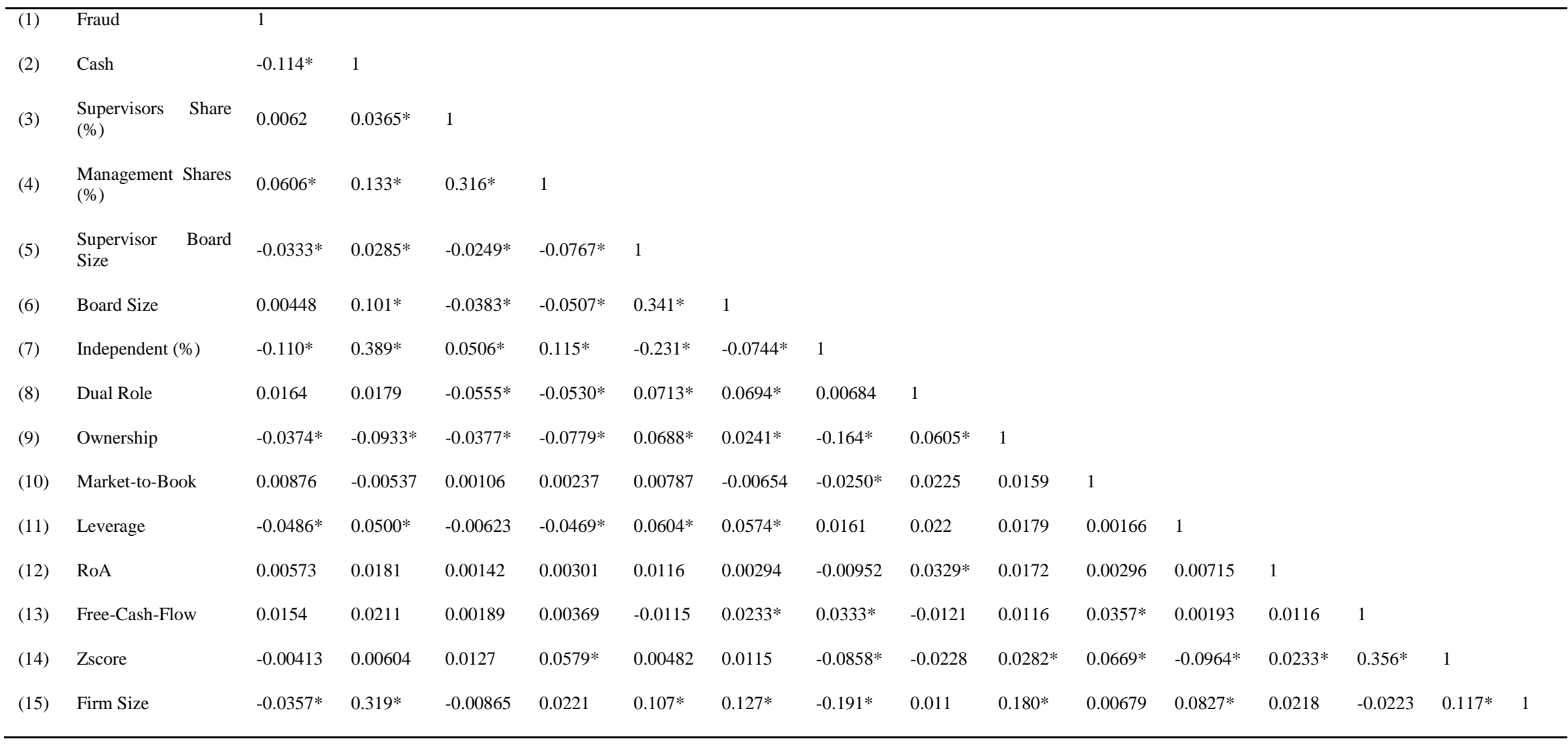


Table 3: Cash Pay, Equity Incentive and Fraud Activities

This table presents results from estimating panel logistic regression of Fraud as a function of equity incentives and control variables. Marginal effects are shown in the table. All variables are as defined in the Appendix. Models 1-3 present the results of Cash and Management Shares (\%), and corporate governance as well as firm characteristic, respectively. Models 4-6 present the results of Cash, Supervisor Shares (\%), and Management Shares (\%), and corporate governance as well as firm characteristic and with all variables jointly, respectively. $t$-statistics are reported in square brackets. ***, **, and * denote statistical significance at the $0.01,0.05$, and 0.1 levels, respectively.

\begin{tabular}{|c|c|c|c|c|c|c|}
\hline & $(1)$ & $(2)$ & (3) & (4) & $(5)$ & $(6)$ \\
\hline \multicolumn{7}{|l|}{ Incentive } \\
\hline$\overline{\text { Cash }}$ & $\begin{array}{c}-0.0341 * * * \\
{[-2.64]}\end{array}$ & $\begin{array}{c}-0.0313^{* *} \\
{[-2.48]}\end{array}$ & $\begin{array}{c}-0.0307 * * \\
{[-2.28]}\end{array}$ & $\begin{array}{c}-0.0316^{* *} \\
{[-2.50]}\end{array}$ & $\begin{array}{c}-0.0309^{* *} \\
{[-2.30]}\end{array}$ & $\begin{array}{c}-0.0373 * * * \\
{[-2.79]}\end{array}$ \\
\hline Supervisors Share (\%) & & & & $\begin{array}{c}-0.00745 \\
{[-0.86]}\end{array}$ & $\begin{array}{c}-0.00812 \\
{[-0.90]}\end{array}$ & $\begin{array}{c}-0.00726 \\
{[-0.87]}\end{array}$ \\
\hline Management Shares (\%) & $\begin{array}{c}0.00615 * * * \\
{[6.97]}\end{array}$ & $\begin{array}{c}0.00572 * * * \\
{[6.64]}\end{array}$ & $\begin{array}{c}0.00600 * * * \\
{[6.98]}\end{array}$ & $\begin{array}{c}0.00605 * * * \\
{[6.51]}\end{array}$ & $\begin{array}{c}0.00636 * * * \\
{[6.86]}\end{array}$ & $\begin{array}{c}0.00608 * * * \\
{[6.65]}\end{array}$ \\
\hline \multicolumn{7}{|c|}{ 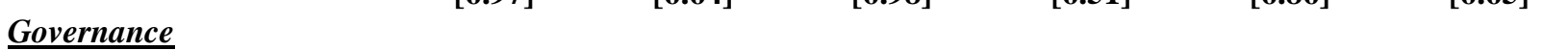 } \\
\hline$\overline{\text { Supervisor Board Size }}$ & & $\begin{array}{c}-0.0124 * * * \\
{[-3.48]}\end{array}$ & & $\begin{array}{c}-0.0122 * * * \\
{[-3.45]}\end{array}$ & & $\begin{array}{c}-0.0111 * * * \\
{[-3.19]}\end{array}$ \\
\hline Board Size & & $\begin{array}{c}0.000161 \\
{[0.08]}\end{array}$ & & $\begin{array}{c}0.000132 \\
{[0.07]}\end{array}$ & & $\begin{array}{c}0.000163 \\
{[0.08]}\end{array}$ \\
\hline Independent (\%) & & $\begin{array}{c}-0.0677 \\
{[-0.61]}\end{array}$ & & $\begin{array}{c}-0.0687 \\
{[-0.62]}\end{array}$ & & $\begin{array}{c}-0.0706 \\
{[-0.65]}\end{array}$ \\
\hline Dual Role & & $\begin{array}{c}0.0126 \\
{[1.16]}\end{array}$ & & $\begin{array}{l}0.0123 \\
{[1.13]}\end{array}$ & & $\begin{array}{l}0.0117 \\
{[1.10]}\end{array}$ \\
\hline Ownership & & $\begin{array}{c}-0.188 * * * \\
{[-5.66]}\end{array}$ & & $\begin{array}{c}-0.189 * * * \\
{[-5.67]}\end{array}$ & & $\begin{array}{c}-0.179 * * * \\
{[-5.29]}\end{array}$ \\
\hline Firm Characteristics & & & & & & \\
\hline Market-to-Book & & & $\begin{array}{c}0.0000526 \\
{[0.47]}\end{array}$ & & $\begin{array}{c}0.0000524 \\
{[0.47]}\end{array}$ & $\begin{array}{c}0.0000349 \\
{[0.61]}\end{array}$ \\
\hline Leverage & & & $\begin{array}{c}-0.151 * * \\
{[-2.30]}\end{array}$ & & $\begin{array}{c}-0.150 * * \\
{[-2.29]}\end{array}$ & $\begin{array}{c}-0.144 * * \\
{[-2.25]}\end{array}$ \\
\hline RoA & & & $\begin{array}{c}0.000134 * * \\
{[2.37]}\end{array}$ & & $\begin{array}{c}0.000134 * * \\
{[2.37]}\end{array}$ & $\begin{array}{c}0.000149 * * \\
{[2.51]}\end{array}$ \\
\hline Free-Cash-Flow & & & $\begin{array}{c}0.00635 \\
{[1.59]}\end{array}$ & & $\begin{array}{c}0.00637 \\
{[1.60]}\end{array}$ & $\begin{array}{c}0.00513 \\
{[1.41]}\end{array}$ \\
\hline Zscore & & & $\begin{array}{c}-0.00129 * \\
{[-1.69]}\end{array}$ & & $\begin{array}{c}-0.00129 * \\
{[-1.69]}\end{array}$ & $\begin{array}{c}-0.00125 \\
{[-1.64]}\end{array}$ \\
\hline Firm Size & & & $\begin{array}{c}-0.00208 \\
{[-0.33]}\end{array}$ & & $\begin{array}{c}-0.00217 \\
{[-0.34]}\end{array}$ & $\begin{array}{c}0.00976 \\
{[1.47]}\end{array}$ \\
\hline Industry Fixed-Effects & Yes & Yes & Yes & Yes & Yes & No \\
\hline Year Fixed-Effects & Yes & Yes & Yes & Yes & Yes & Yes \\
\hline Observations & 5236 & 5196 & 5228 & 5196 & 5228 & 5188 \\
\hline Pseudo R2 & 0.087 & 0.099 & 0.092 & 0.099 & 0.092 & 0.101 \\
\hline
\end{tabular}


Table 4 : Cash Pay, Equity Incentive and Fraud Activities for State-Owned Firms

This table presents results from estimating panel logistic regression of Fraud as a function of equity incentives and control variables for SOEs (State Owned Enterprises). Marginal effects are shown in the table. All variables are as defined in the Appendix. Models 1-3 present the results of Cash and Management Shares (\%), and corporate governance as well as firm characteristic, respectively. Models 4-6 present the results of Cash, Supervisor Shares (\%), and Management Shares (\%), and corporate governance as well as firm characteristic and with all variables jointly, respectively. Models 1-3 present the results of Cash and Management Shares (\%), and corporate governance as well as firm characteristic, respectively. Models 4-6 present the results of Cash, Supervisor Shares (\%), and Management Shares (\%), and corporate governance as well as firm characteristic and with all variables jointly, respectively. t-statistics are reported in square brackets. $* * *, * *$, and $*$ denote statistical significance at the $0.01,0.05$, and 0.1 levels, respectively.

\begin{tabular}{|c|c|c|c|c|c|c|}
\hline & $(1)$ & $(2)$ & (3) & $(4)$ & $(5)$ & $(6)$ \\
\hline \multicolumn{7}{|l|}{ Incentive } \\
\hline$\overline{\text { Cash }}$ & $\begin{array}{c}-0.0352 * * \\
{[-2.00]}\end{array}$ & $\begin{array}{c}-0.0357 * * \\
{[-1.99]}\end{array}$ & $\begin{array}{c}-0.0317 * \\
{[-1.87]}\end{array}$ & $\begin{array}{c}-0.0359 * * \\
{[-2.00]}\end{array}$ & $\begin{array}{c}-0.0319 * \\
{[-1.88]}\end{array}$ & $\begin{array}{c}-0.0432 * * \\
{[-2.48]}\end{array}$ \\
\hline Supervisors Share (\%) & & & & $\begin{array}{c}-0.00546 \\
{[-0.25]}\end{array}$ & $\begin{array}{c}-0.00482 \\
{[-0.24]}\end{array}$ & $\begin{array}{c}-0.00569 \\
{[-0.28]}\end{array}$ \\
\hline Management Shares (\%) & $\begin{array}{c}0.00785 * * * \\
{[3.41]}\end{array}$ & $\begin{array}{c}0.00773^{* * * *} \\
{[3.55]}\end{array}$ & $\begin{array}{c}0.00700 * * * \\
{[3.47]}\end{array}$ & $\begin{array}{c}0.00823 * * * \\
{[2.63]}\end{array}$ & $\begin{array}{c}0.00744 * * \\
{[2.57]}\end{array}$ & $\begin{array}{c}0.00730 * * \\
{[2.49]}\end{array}$ \\
\hline \multicolumn{7}{|l|}{ Governance } \\
\hline$\overline{\text { Supervisor Board Size }}$ & & $\begin{array}{c}-0.0139 * * * \\
{[-2.72]}\end{array}$ & & $\begin{array}{c}-0.0139 * * * \\
{[-2.72]}\end{array}$ & & $\begin{array}{c}-0.0112 * * \\
{[-2.38]}\end{array}$ \\
\hline Board Size & & $\begin{array}{c}0.00363 \\
{[1.27]}\end{array}$ & & $\begin{array}{c}0.00362 \\
{[1.27]}\end{array}$ & & $\begin{array}{c}0.00287 \\
{[1.10]}\end{array}$ \\
\hline Independent (\%) & & $\begin{array}{l}-0.148 \\
{[-0.87]}\end{array}$ & & $\begin{array}{l}-0.148 \\
{[-0.87]}\end{array}$ & & $\begin{array}{l}-0.127 \\
{[-0.80]}\end{array}$ \\
\hline Dual Role & & $\begin{array}{c}0.0204 \\
{[1.23]}\end{array}$ & & $\begin{array}{c}0.0203 \\
{[1.23]}\end{array}$ & & $\begin{array}{l}0.0192 \\
{[1.27]}\end{array}$ \\
\hline Ownership & & $\begin{array}{c}-0.191 * * * \\
{[-4.35]}\end{array}$ & & $\begin{array}{c}-0.192 * * * \\
{[-4.36]}\end{array}$ & & $\begin{array}{c}-0.170 * * * \\
{[-3.81]}\end{array}$ \\
\hline \multicolumn{7}{|l|}{ Firm Characteristics } \\
\hline Market-to-Book & & & $\begin{array}{c}0.0000137 \\
{[0.50]}\end{array}$ & & $\begin{array}{c}0.0000137 \\
{[0.50]}\end{array}$ & $\begin{array}{c}0.00000827 \\
{[0.31]}\end{array}$ \\
\hline Leverage & & & $\begin{array}{c}-0.180 * * * \\
{[-2.61]}\end{array}$ & & $\begin{array}{c}-0.180 * * * \\
{[-2.61]}\end{array}$ & $\begin{array}{c}-0.165 * * \\
{[-2.39]}\end{array}$ \\
\hline RoA & & & $\begin{array}{c}0.000148 * * \\
{[2.49]}\end{array}$ & & $\begin{array}{c}0.000148^{* *} \\
{[2.50]}\end{array}$ & $\begin{array}{c}0.000158 * * * \\
{[2.62]}\end{array}$ \\
\hline Free-Cash-Flow & & & $\begin{array}{c}0.0227 * * * \\
{[3.20]}\end{array}$ & & $\begin{array}{c}0.0227 * * * \\
{[3.21]}\end{array}$ & $\begin{array}{c}0.0191 * * * \\
{[2.71]}\end{array}$ \\
\hline Zscore & & & $\begin{array}{c}-0.00143 \\
{[-0.83]}\end{array}$ & & $\begin{array}{c}-0.00142 \\
{[-0.83]}\end{array}$ & $\begin{array}{c}-0.00133 \\
{[-0.87]}\end{array}$ \\
\hline Firm Size & & & $\begin{array}{c}0.00328 \\
{[0.41]}\end{array}$ & & $\begin{array}{c}0.00324 \\
{[0.41]}\end{array}$ & $\begin{array}{c}0.0144 * \\
{[1.68]}\end{array}$ \\
\hline Industry Fixed-Effects & Yes & Yes & Yes & Yes & Yes & No \\
\hline Year Fixed-Effects & Yes & Yes & Yes & Yes & Yes & Yes \\
\hline Observations & 3301 & 3278 & 3298 & 3278 & 3298 & 3275 \\
\hline Pseudo R2 & 0.050 & 0.060 & 0.059 & 0.060 & 0.060 & 0.064 \\
\hline
\end{tabular}


Table 5 : Cash Pay, Equity Incentive and Fraud Activities for Non-State-Owned Firms

This table presents results from estimating panel logistic regression of Fraud as a function of equity incentives and control variables for non-SOEs (non-state-owned enterprises). Marginal effects are shown in the table. All variables are as defined in the Appendix. Models 1-3 present the results of Cash and Management Shares (\%), and corporate governance as well as firm characteristic, respectively. Models 4-6 present the results of Cash, Supervisor Shares (\%), and Management Shares (\%), and corporate governance as well as firm characteristic and with all variables jointly, respectively. t-statistics are reported in square brackets. ***, **, and * denote statistical significance at the $0.01,0.05$, and 0.1 levels, respectively.

\begin{tabular}{|c|c|c|c|c|c|c|}
\hline & (1) & (2) & (3) & (4) & (5) & (6) \\
\hline \multicolumn{7}{|l|}{ Incentive } \\
\hline Cash & $\begin{array}{c}-0.0338^{*} \\
{[-1.71]}\end{array}$ & $\begin{array}{c}-0.0303 * \\
{[-1.67]}\end{array}$ & $\begin{array}{l}-0.0247 \\
{[-1.14]}\end{array}$ & $\begin{array}{c}-0.0308 * \\
{[-1.69]}\end{array}$ & $\begin{array}{c}-0.0253 \\
{[-1.17]}\end{array}$ & $\begin{array}{c}-0.0280 \\
{[-1.36]}\end{array}$ \\
\hline Supervisors Share (\%) & & & & $\begin{array}{c}-0.00856 \\
{[-0.64]}\end{array}$ & $\begin{array}{c}-0.00998 \\
{[-0.72]}\end{array}$ & $\begin{array}{c}-0.00812 \\
{[-0.74]}\end{array}$ \\
\hline Management Shares (\%) & $\begin{array}{c}0.00482 * * * \\
{[5.27]}\end{array}$ & $\begin{array}{c}0.00439 * * * \\
{[4.99]}\end{array}$ & $\begin{array}{c}0.00485 * * * \\
{[5.30]}\end{array}$ & $\begin{array}{c}0.00466 * * * \\
{[4.89]}\end{array}$ & $\begin{array}{c}0.00516 * * * \\
{[5.22]}\end{array}$ & $\begin{array}{c}0.00489 * * * \\
{[5.27]}\end{array}$ \\
\hline \multicolumn{7}{|l|}{ Governance } \\
\hline$\overline{\text { Supervisor Board Size }}$ & & $\begin{array}{c}-0.0128 * * \\
{[-2.21]}\end{array}$ & & $\begin{array}{c}-0.0126 * * \\
{[-2.18]}\end{array}$ & & $\begin{array}{c}-0.0101 * \\
{[-1.76]}\end{array}$ \\
\hline Board Size & & $\begin{array}{c}-0.00412 \\
{[-1.33]}\end{array}$ & & $\begin{array}{c}-0.00414 \\
{[-1.34]}\end{array}$ & & $\begin{array}{c}-0.00316 \\
{[-0.99]}\end{array}$ \\
\hline Independent (\%) & & $\begin{array}{c}-0.0124 \\
{[-0.09]}\end{array}$ & & $\begin{array}{c}-0.0134 \\
{[-0.09]}\end{array}$ & & $\begin{array}{c}-0.0124 \\
{[-0.09]}\end{array}$ \\
\hline Dual Role & & $\begin{array}{c}0.00687 \\
{[0.47]}\end{array}$ & & $\begin{array}{c}0.00654 \\
{[0.44]}\end{array}$ & & $\begin{array}{c}0.00261 \\
{[0.17]}\end{array}$ \\
\hline Ownership & & $\begin{array}{c}-0.192 * * * \\
{[-3.02]}\end{array}$ & & $\begin{array}{c}-0.192 * * * \\
{[-3.03]}\end{array}$ & & $\begin{array}{c}-0.182 * * * \\
{[-2.92]}\end{array}$ \\
\hline \multicolumn{7}{|l|}{ Firm Characteristics } \\
\hline Market-to-Book & & & $\begin{array}{c}0.000519 * \\
{[1.88]}\end{array}$ & & $\begin{array}{c}0.000517 * \\
{[1.88]}\end{array}$ & $\begin{array}{c}0.000453 \\
{[1.55]}\end{array}$ \\
\hline Leverage & & & $\begin{array}{c}-0.0313 \\
{[-0.35]}\end{array}$ & & $\begin{array}{c}-0.0298 \\
{[-0.34]}\end{array}$ & $\begin{array}{c}-0.0795 \\
{[-0.79]}\end{array}$ \\
\hline RoA & & & $\begin{array}{c}-0.00475 \\
{[-0.34]}\end{array}$ & & $\begin{array}{c}-0.00473 \\
{[-0.34]}\end{array}$ & $\begin{array}{c}-0.000960 \\
{[-0.07]}\end{array}$ \\
\hline Free-Cash-Flow & & & $\begin{array}{c}0.000879 \\
{[0.75]}\end{array}$ & & $\begin{array}{c}0.000882 \\
{[0.76]}\end{array}$ & $\begin{array}{c}0.000959 \\
{[0.83]}\end{array}$ \\
\hline Zscore & & & $\begin{array}{c}-0.000853 \\
{[-1.42]}\end{array}$ & & $\begin{array}{c}-0.000855 \\
{[-1.44]}\end{array}$ & $\begin{array}{c}-0.000970 * \\
{[-1.72]}\end{array}$ \\
\hline Firm Size & & & $\begin{array}{c}-0.00828 \\
{[-0.72]}\end{array}$ & & $\begin{array}{c}-0.00829 \\
{[-0.73]}\end{array}$ & $\begin{array}{c}0.00274 \\
{[0.24]}\end{array}$ \\
\hline Industry Fixed-Effects & Yes & Yes & Yes & Yes & Yes & No \\
\hline Year Fixed-Effects & Yes & Yes & Yes & Yes & Yes & Yes \\
\hline Observations & 1774 & 1763 & 1773 & 1763 & 1773 & 1766 \\
\hline Pseudo R2 & 0.155 & 0.167 & 0.158 & 0.167 & 0.159 & 0.161 \\
\hline
\end{tabular}




\section{Table 6: Robustness Test}

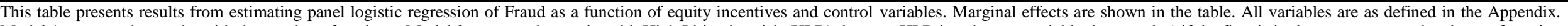

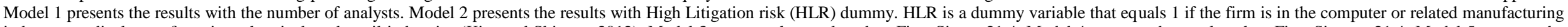

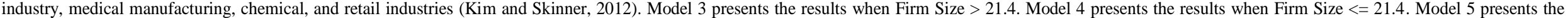

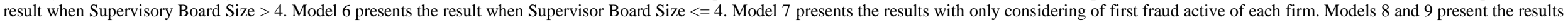

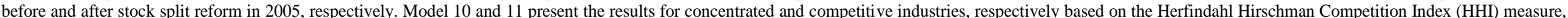

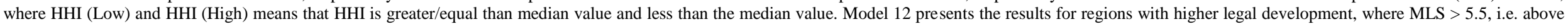

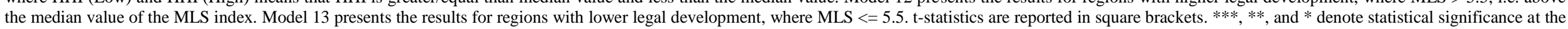
$0.01,0.05$, and 0.1 levels, respectively.

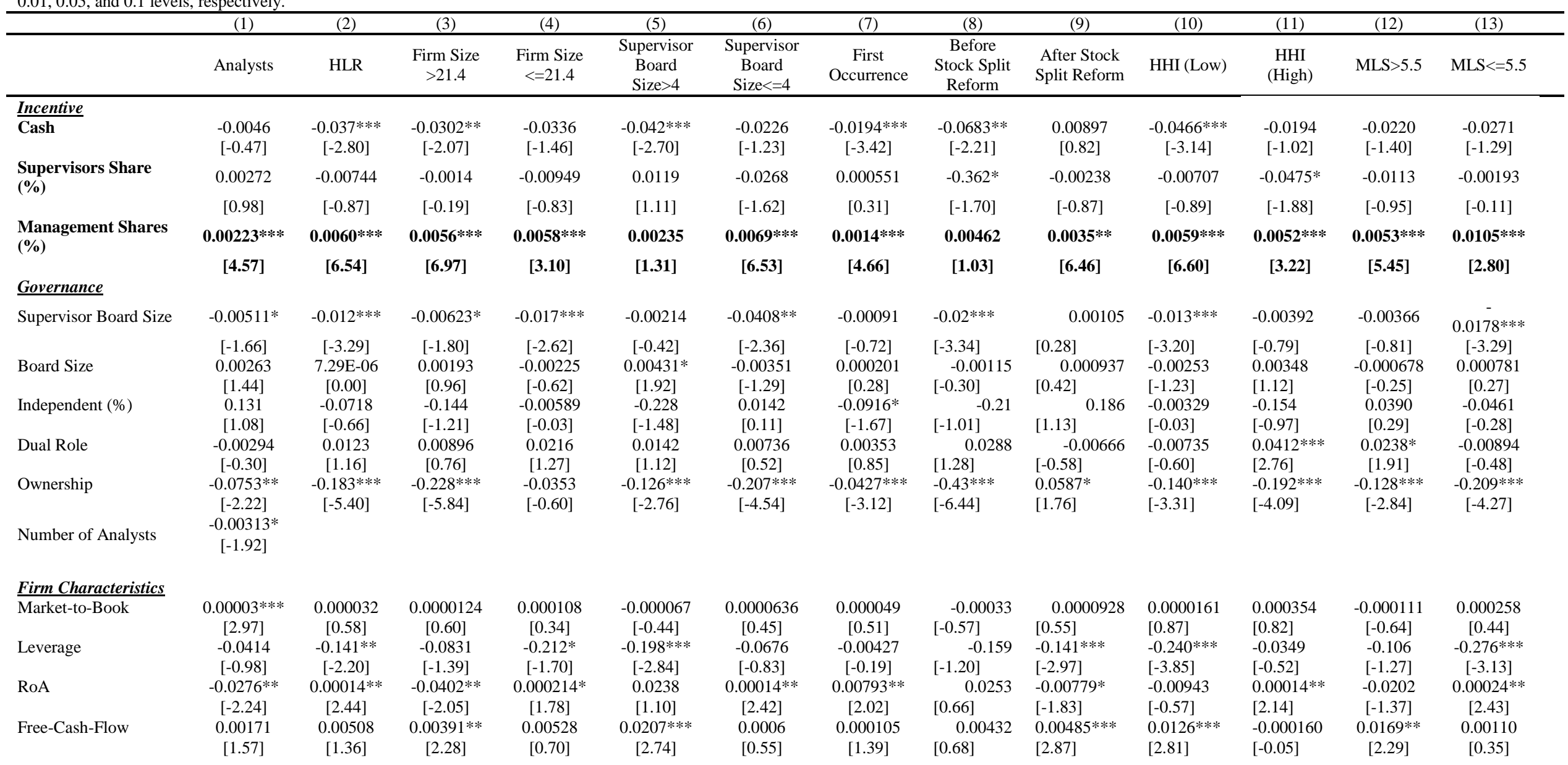




\section{Table 6 continued: Robustness Test}

\begin{tabular}{|c|c|c|c|c|c|c|c|c|c|c|c|c|c|}
\hline Zscore & $\begin{array}{c}-0.0031 \text { *** } \\
{[-2.92]}\end{array}$ & $\begin{array}{c}-0.00122 \\
{[-1.60]}\end{array}$ & $\begin{array}{c}-0.00075 \\
{[-0.95]}\end{array}$ & $\begin{array}{c}-0.00175^{* *} \\
{[-2.29]}\end{array}$ & $\begin{array}{c}-0.00276 \\
{[-1.62]}\end{array}$ & $\begin{array}{c}-0.000561 \\
{[-0.64]}\end{array}$ & $\begin{array}{c}0.00022 \\
{[1.61]}\end{array}$ & $\begin{array}{c}-0.00169 \\
{[-0.86]}\end{array}$ & $\begin{array}{c}-0.000126 \\
{[-0.28]}\end{array}$ & $\begin{array}{l}-0.00125 \\
{[-1.32]}\end{array}$ & $\begin{array}{l}-0.00100 \\
{[-1.23]}\end{array}$ & $\begin{array}{c}-0.000676 \\
{[-0.83]}\end{array}$ & $\begin{array}{c}-0.00235 \\
{[-1.38]}\end{array}$ \\
\hline Firm Size & $\begin{array}{c}0.00428 \\
{[0.64]}\end{array}$ & $\begin{array}{c}0.00984 \\
{[1.48]}\end{array}$ & $\begin{array}{l}0.0135 \\
{[1.44]}\end{array}$ & $\begin{array}{c}0.0229 * \\
{[1.67]}\end{array}$ & $\begin{array}{c}0.0242 * * * * \\
{[2.95]}\end{array}$ & $\begin{array}{c}-0.0134 \\
{[-1.47]}\end{array}$ & $\begin{array}{c}0.00665^{* * *} \\
{[2.45]}\end{array}$ & $\begin{array}{c}0.0247 \\
{[1.64]}\end{array}$ & $\begin{array}{l}-0.0132 * * \\
{[-2.52]}\end{array}$ & $\begin{array}{l}0.00757 \\
{[0.96]}\end{array}$ & $\begin{array}{l}0.0132 \\
{[1.49]}\end{array}$ & $\begin{array}{c}-0.0135^{*} \\
{[-1.66]}\end{array}$ & $\begin{array}{c}0.0393 * * * * \\
{[3.75]}\end{array}$ \\
\hline High Litigation Risk & & $\begin{array}{l}0.0111 \\
{[1.34]}\end{array}$ & & & & & & & & & & & \\
\hline Industry Fixed-Effects & Yes & No & Yes & Yes & Yes & Yes & Yes & No & No & No & No & No & No \\
\hline Year Fixed-Effects & Yes & Yes & Yes & Yes & Yes & Yes & Yes & Yes & Yes & Yes & Yes & Yes & Yes \\
\hline Observations & 1429 & 5188 & 2595 & 2593 & 2261 & 2920 & 5188 & 2429 & 2756 & 2576 & 2612 & 2486 & 2556 \\
\hline Pseudo R2 & 0.237 & 0.101 & 0.152 & 0.076 & 0.115 & 0.122 & 0.125 & 0.032 & 0.131 & 0.1514 & 0.0792 & 0.117 & 0.113 \\
\hline
\end{tabular}


Table 7: Robustness Check with Full Dataset

This table presents results from estimating panel logistic regression of Fraud as a function of equity incentives and control variables for the full sample. Marginal effects are shown in the table. All variables are as defined in the Appendix. Models 1 and 2 present the results for the full sample, models 3 and 4 present the results for SOEs, and models 5 and 6 Present those for non-SOEs. t-statistics are reported in square brackets. $* * *, * *$, and $*$ denote statistical significance at the $0.01,0.05$, and 0.1 levels, respectively.

\begin{tabular}{|c|c|c|c|c|c|c|}
\hline & \multicolumn{2}{|c|}{ Overall } & \multicolumn{2}{|c|}{ State Owned Firms } & \multicolumn{2}{|c|}{ Non-State Owned Firms } \\
\hline & (1) & (2) & $(1)$ & $(2)$ & $(1)$ & $(2)$ \\
\hline \multicolumn{7}{|l|}{ Incentive } \\
\hline Cash & $\begin{array}{c}-0.0155 * * * \\
{[-3.69]}\end{array}$ & $\begin{array}{c}-0.0184 * * * \\
{[-4.45]}\end{array}$ & $\begin{array}{c}-0.0210 * * * \\
{[-3.36]}\end{array}$ & $\begin{array}{c}-0.0281 * * * \\
{[-4.51]}\end{array}$ & $\begin{array}{c}-0.0122 * \\
{[-1.88]}\end{array}$ & $\begin{array}{c}-0.0108 * \\
{[-1.78]}\end{array}$ \\
\hline Supervisors Share (\%) & $\begin{array}{c}-0.00499 \\
{[-1.55]}\end{array}$ & $\begin{array}{c}-0.00509 \\
{[-1.62]}\end{array}$ & $\begin{array}{c}-0.00146 \\
{[-0.30]}\end{array}$ & $\begin{array}{c}-0.00247 \\
{[-0.48]}\end{array}$ & $\begin{array}{c}-0.00589 \\
{[-1.28]}\end{array}$ & $\begin{array}{c}-0.00582 \\
{[-1.33]}\end{array}$ \\
\hline Management Shares (\%) & $\begin{array}{c}0.00234 * * * \\
{[8.13]}\end{array}$ & $\begin{array}{c}0.00218 * * * \\
{[7.62]}\end{array}$ & $\begin{array}{c}0.00323 * * * \\
{[3.65]}\end{array}$ & $\begin{array}{c}0.00311 * * * \\
{[3.46]}\end{array}$ & $\begin{array}{c}0.00162 * * * \\
{[5.51]}\end{array}$ & $\begin{array}{c}0.00153 * * * \\
{[5.51]}\end{array}$ \\
\hline \multicolumn{7}{|l|}{ Governance } \\
\hline Supervisor Board Size & & $\begin{array}{c}-0.00373 * * * \\
{[-3.97]}\end{array}$ & & $\begin{array}{c}-0.00566 * * * \\
{[-3.70]}\end{array}$ & & $\begin{array}{c}-0.00186 \\
{[-1.37]}\end{array}$ \\
\hline Board Size & & $\begin{array}{c}-0.000327 \\
{[-0.59]}\end{array}$ & & $\begin{array}{c}0.000597 \\
{[0.65]}\end{array}$ & & $\begin{array}{c}-0.00128 * \\
{[-1.66]}\end{array}$ \\
\hline Independent (\%) & & $\begin{array}{c}-0.0301 \\
{[-1.00]}\end{array}$ & & $\begin{array}{c}-0.0622 \\
{[-1.15]}\end{array}$ & & $\begin{array}{c}-0.00779 \\
{[-0.22]}\end{array}$ \\
\hline Dual Role & & $\begin{array}{c}0.00319 \\
{[1.09]}\end{array}$ & & $\begin{array}{c}0.00613 \\
{[1.17]}\end{array}$ & & $\begin{array}{c}0.00104 \\
{[0.29]}\end{array}$ \\
\hline Ownership & & $\begin{array}{c}-0.0732 * * * \\
{[-7.13]}\end{array}$ & & $\begin{array}{c}-0.0960 * * * \\
{[-6.20]}\end{array}$ & & $\begin{array}{c}-0.0578 * * * \\
{[-3.42]}\end{array}$ \\
\hline \multicolumn{7}{|l|}{ Firm Characteristics } \\
\hline$\overline{\text { Market-to-Book }}$ & $\begin{array}{c}0.0000777 \\
{[1.08]}\end{array}$ & $\begin{array}{c}0.0000424 \\
{[0.59]}\end{array}$ & $\begin{array}{c}0.0000175 \\
{[0.63]}\end{array}$ & $\begin{array}{c}0.00000676 \\
{[0.45]}\end{array}$ & $\begin{array}{c}0.000118 \\
{[1.45]}\end{array}$ & $\begin{array}{c}0.0000992 \\
{[1.19]}\end{array}$ \\
\hline Leverage & $\begin{array}{c}-0.0470 * * * \\
{[-2.60]}\end{array}$ & $\begin{array}{c}-0.0427 * * \\
{[-2.41]}\end{array}$ & $\begin{array}{c}-0.0693 * * * \\
{[-3.04]}\end{array}$ & $\begin{array}{c}-0.0638 * * * \\
{[-2.77]}\end{array}$ & $\begin{array}{c}-0.0151 \\
{[-0.60]}\end{array}$ & $\begin{array}{c}-0.0205 \\
{[-0.75]}\end{array}$ \\
\hline RoA & $\begin{array}{c}0.0000322 * * \\
{[2.12]}\end{array}$ & $\begin{array}{c}0.0000282 * \\
{[1.90]}\end{array}$ & $\begin{array}{c}0.0000475^{* *} * \\
{[2.27]}\end{array}$ & $\begin{array}{c}0.0000395 * \\
{[1.92]}\end{array}$ & $\begin{array}{c}-0.00161 \\
{[-0.78]}\end{array}$ & $\begin{array}{c}-0.00114 \\
{[-0.47]}\end{array}$ \\
\hline Free-Cash-Flow & $\begin{array}{c}0.00157 * * * \\
{[2.93]}\end{array}$ & $\begin{array}{c}0.00166^{* * * *} \\
{[3.28]}\end{array}$ & $\begin{array}{c}0.00226 * * * \\
{[2.61]}\end{array}$ & $\begin{array}{c}0.00253 * * * \\
{[2.72]}\end{array}$ & $\begin{array}{c}0.000769 \\
{[0.63]}\end{array}$ & $\begin{array}{c}0.000678 \\
{[0.66]}\end{array}$ \\
\hline Zscore & $\begin{array}{c}-0.000419 * * \\
{[-2.25]}\end{array}$ & $\begin{array}{c}-0.000434 * * \\
{[-2.10]}\end{array}$ & $\begin{array}{c}-0.000541 \\
{[-1.42]}\end{array}$ & $\begin{array}{c}-0.000503 \\
{[-1.06]}\end{array}$ & $\begin{array}{c}-0.000323^{* *} \\
{[-2.05]}\end{array}$ & $\begin{array}{c}-0.000351 * * \\
{[-2.25]}\end{array}$ \\
\hline Firm Size & $\begin{array}{c}-0.0115 * * * \\
{[-6.88]}\end{array}$ & $\begin{array}{c}-0.00684 * * * \\
{[-4.03]}\end{array}$ & $\begin{array}{c}-0.0148 * * * \\
{[-6.05]}\end{array}$ & $\begin{array}{c}-0.00779 * * * \\
{[-2.84]}\end{array}$ & $\begin{array}{c}-0.00910 * * * \\
{[-3.46]}\end{array}$ & $\begin{array}{c}-0.00675 * * * \\
{[-2.73]}\end{array}$ \\
\hline Industry Fixed-Effects & Yes & No & Yes & No & Yes & No \\
\hline Year Fixed-Effects & Yes & Yes & Yes & Yes & Yes & Yes \\
\hline Observations & 13006 & 12921 & 8062 & 8008 & 4437 & 4423 \\
\hline R-squared & 0.135 & 0.142 & 0.097 & 0.100 & 0.204 & 0.210 \\
\hline
\end{tabular}

